\title{
Immune Modulation as a Therapeutic Option During the SARS-CoV-2 Outbreak: The Case for Antimalarial Aminoquinolines
}

\author{
Joana Vitte ${ }^{1,2}$, Moïse Michel ${ }^{1,2}$, Soraya Mezouar ${ }^{1,2}$, Aïssatou Bailo Diallo ${ }^{1,2}$, \\ Asma Boumaza $^{1,2}$, Jean-Louis Mege ${ }^{1,2}$ and Benoit Desnues ${ }^{1,2 *}$ \\ ${ }^{1}$ Aix Marseille Univ, IRD, APHM, MEPHI, Marseille, France, ${ }^{2}$ IHU-Méditerranée Infection, Marseille, France
}

OPEN ACCESS

Edited by:

Julia Kzhyshkowska,

Heidelberg University, Germany

Reviewed by:

Srinivasa Reddy Bonam,

Institut National de la Santé et de la Recherche Médicale (INSERM), France

Luuk Hilbrands,

Radboud University

Nijmegen, Netherlands

*Correspondence:

Benoit Desnues

benoit.desnues@univ-amu.fr

Specialty section:

This article was submitted to

Vaccines and Molecular Therapeutics,

a section of the journal

Frontiers in Immunology

Received: 30 May 2020 Accepted: 07 August 2020 Published: 28 August 2020

Citation: Vitte J, Michel M, Mezouar S, Diallo AB, Boumaza A, Mege J-L and Desnues B (2020) Immune Modulation as a Therapeutic Option During the SARS-CoV-2 Outbreak: The Case for Antimalarial Aminoquinolines.

Front. Immunol. 11:2159. doi: 10.3389/fimmu.2020.02159
The rapid spread, severity, and lack of specific treatment for COVID-19 resulted in hasty drug repurposing. Conceptually, trials of antivirals were well-accepted, but twentieth century antimalarials sparked an impassioned global debate. Notwithstanding, antiviral and immunomodulatory effects of aminoquinolines have been investigated in vitro, in vivo and in clinical trials for more than 30 years. We review the mechanisms of action of (hydroxy)chloroquine on immune cells and networks and discuss promises and pitfalls in the fight against SARS-CoV-2, the agent of the COVID-19 outbreak.

Keywords: COVID-19, SARS-CoV-2, chloroquine, hydroxychloroquine, immune modulation

\section{INTRODUCTION}

The rapid spread and severity of the coronavirus disease 2019 (COVID-19) have been accentuated by the lack of a specific treatment and resulted in hasty drug repurposing. Conceptually, trials of molecules like remdesivir or lopinavir already used for combatting emergent viruses were well-accepted. Conversely, repurposing drugs that collective memory associated with twentieth century antimalarial treatment sparked an impassioned global debate. Notwithstanding, antiviral and immunomodulatory effects of chloroquine (CQ) and hydroxychloroquine (HCQ), now including Severe Acute Respiratory Syndrome Coronavirus 2 (SARS-CoV-2), have been investigated for more than 30 years in vitro, in vivo and in clinical trials (1-3). Among 2,654 clinical trials on COVID-19 registered with Clinicaltrials.gov from 43 countries and all continents by mid-July 2020, 239 included HCQ treatment or prophylaxis while 82 addressed CQ (clinicaltrials.gov, accessed July 17, 2020). At the same date, published available results were scarce, with only 13 papers identified as clinical trials in a PubMed search with the filters HCQ and 1 year, and 20 for CQ (pubmed.ncbi.nlm.nih.gov, accessed July 17, 2020). Here, we will review and comment $\mathrm{CQ} / \mathrm{HCQ}$ effects on immune responses, aiming to identify their promises and pitfalls in the fight against SARS-CoV-2, the agent of the COVID-19 outbreak.

\section{HCQ AND CQ: BASIC KNOWLEDGE OF STRUCTURE AND CHEMISTRY}

CQ and HCQ belong to the chemical class of quinolines, which has been intensively investigated for the development of potent antimalarial agents. Antimalarial quinoline derivatives belong to three main categories: the 4-aminoquinolines, which include CQ, HCQ, amodiaquine, and ferroquine, the 4-methanoquinolines, represented by quinine, quinidine, and mefloquine, and the 
8 -aminoquinolines, comprising primaquine and pamaquine, the latter also known as plasmoquine (Figure 1). CQ-resistance was soon evolved by Plasmodium falciparum, resulting in discontinued therapeutic and prophylactic use (4). Yet, it was observed during World War II that soldiers receiving CQ antimalarial prophylaxis experienced anti-inflammatory effects and attenuated arthritis symptoms. Currently, CQ and HCQ have been cleared by the US Food and Drug Administration (FDA) for rheumatoid arthritis (RA) and systemic lupus erythematosus (SLE), while clinical research trials are in progress for Sjögren's syndrome, graft-vs.-host disease, cancer, and nanomedicine approaches (5-9). CQ and HCQ also demonstrated antiviral (10-12), antibacterial (13-15), antifungal (16), and immunomodulatory $(17,18)$ properties, resulting from distinct, yet not fully characterized mechanisms (16). Aminoquinolines are not an isolated example of antimalarials repurposed for emerging and re-emerging viral infections. Artemisinin derivatives, methanoquinolines, and antimicrobial drugs are further examples (Table 1).

$\mathrm{CQ} / \mathrm{HCQ}$ are amphiphilic, diprotic weak bases $\left(\mathrm{pK}_{\mathrm{a} 1}=\right.$ 8.1, $\mathrm{pK}_{\mathrm{a} 2}=10.2$ and $\mathrm{pK}_{\mathrm{a} 1}=8.3, \mathrm{pK}_{\mathrm{a} 2}=9.7$ at $37^{\circ} \mathrm{C}$, respectively). As conjugate bases, $\mathrm{CQ} / \mathrm{HCQ}$ freely cross plasma and organelle membranes, then accumulate in acidic intracellular compartments, e.g., microsomes, endosomes, and lysosomes, where they act as proton acceptors $(4,19)$. Consequently, these lysosomotropic agents interfere with organelle and lysosome acidification. Lysosomes are intracellular compartments hosting vital processes such as lipid metabolism, energy production, intracellular trafficking, and cell signaling (20). The latter requires the assembly of critical protein complexes, e.g., molecular target of rapamycin complex 1 (mTORC1) on lysosomal membranes and the regulation of the lysosomal store of $\mathrm{Ca}^{2+}$ which can be

\section{4-aminoquinolines}<smiles>CCN(CC)CCCC(C)Nc1ccnc2cc(Cl)ccc12</smiles>

chloroquine<smiles>CCN(CCO)CCCC(C)Nc1ccnc2cc(Cl)ccc12</smiles>

hydroxychloroquine<smiles>CCN(CC)Cc1cc(Nc2ccnc3cc(Cl)ccc23)ccc1O</smiles>

amodiaquine<smiles>CN(C)CC1CCCC1CNc1ccnc2cc(Cl)ccc12</smiles>

ferroquine

\section{4-methanoquinolines}<smiles>C=CC1CN2CCC1C[C@H]2[C@H](O)c1ccnc2ccc(OC)cc12</smiles>

quinine<smiles>C=CC1CN2CCC1CC2[C@H](O)c1ccnc2ccc(OC)cc12</smiles>

quinidine<smiles>O[C@@H](c1cc(C(F)(F)F)nc2c(C(F)(F)F)cccc12)[C@H]1CCCCN1</smiles>

mefloquine

\section{8-aminoquinolines}<smiles>COc1cc(NC(C)CCCN)c2ncccc2c1</smiles>

primaquine<smiles>CCN(CC)CCCC(C)Nc1cc(OC)cc2cccnc12</smiles>

pamaquine

FIGURE 1 | Skeletal structures of some quinoline-based antimalarial drugs. Structures were taken from https://www.chemspider.com/ (with written permission). 
TABLE 1 | Antimalarial drugs with antiviral actions.

\begin{tabular}{|c|c|c|c|c|c|c|}
\hline \multirow[b]{2}{*}{ Name } & \multirow{2}{*}{$\begin{array}{l}\text { Methanoquinolines } \\
\text { Quinine/quinidine, } \\
\text { mefloquine }\end{array}$} & \multirow{2}{*}{$\begin{array}{l}\text { Aminoquinolines } \\
\text { Chloroquine, } \\
\text { hydroxychloroquine, } \\
\text { amodiaquine, ferroquine, } \\
\text { primaquine, pamaquine }\end{array}$} & \multirow{2}{*}{$\begin{array}{l}\text { Artemisinin derivates } \\
\text { Artemisinin, } \\
\text { dihydroartemisinin, } \\
\text { artesunate, artemether }\end{array}$} & \multicolumn{3}{|c|}{ Antibiotics } \\
\hline & & & & Doxycycline & Sulfonamides & Atovaquone \\
\hline Origin & $\begin{array}{l}\text { Quinine/quinidine: } \\
\text { alkaloid enantiomers } \\
\text { from Chinchona } \\
\text { officinalis } \\
\text { Mefloquine: } \\
\text { synthetic derivation } \\
\text { of quinine }\end{array}$ & Synthetic derivation of quinine & $\begin{array}{l}\text { Artemisinin: sesquiterpene } \\
\text { lactone from Artemisia annua } \\
\text { Dihydroartemisinin, artesunate } \\
\text { and artemether: synthetic } \\
\text { derivation of artemisinin }\end{array}$ & $\begin{array}{l}\text { Synthetic } \\
\text { derivation of } \\
\text { oxytetracycline }\end{array}$ & $\begin{array}{l}\text { Synthetic } \\
\text { derivation of } \\
\text { sulfonic acid }\end{array}$ & $\begin{array}{l}\text { Synthetic } \\
\text { naphtoquinone }\end{array}$ \\
\hline $\begin{array}{l}\text { Discovery/1st } \\
\text { report }\end{array}$ & $\begin{array}{l}\text { Seventeenth century } \\
\text { (quinine/quinidine), } \\
1974 \text { (mefloquine) }\end{array}$ & $\begin{array}{l}1934 \text { (chloroquine), } 1949 \\
\text { (hydroxychloroquine), } 1948 \\
\text { (amodiaquine), } 1994 \\
\text { (ferroquine), } 1946 \\
\text { (primaquine), } 1926 \\
\text { (pamaquine) }\end{array}$ & $\begin{array}{l}1972 \text { (artemisinin), } 1986 \\
\text { (dihyroartemisinin), } 1987 \\
\text { (artesunate and artemether) }\end{array}$ & 1957 & 1935 & 1991 \\
\hline $\begin{array}{l}\text { Anti-malarial } \\
\text { mode of action }\end{array}$ & \multicolumn{2}{|c|}{$\begin{array}{c}\text { Inhibition of parasite heme polymerase, } \\
\text { preventing the conversion of heme to } \\
\text { hemazoin }\end{array}$} & $\begin{array}{l}\text { Binding and cleavage of } \\
\text { intraparasitic heme-iron to } \\
\text { produce toxic free radicals }\end{array}$ & $\begin{array}{l}\text { Inhibition of } \\
\text { apicoplast protein } \\
\text { synthesis }\end{array}$ & $\begin{array}{l}\text { Inhibition of } \\
\text { dihydropteroate } \\
\text { synthetase and } \\
\text { dihydrofolate } \\
\text { reductase }\end{array}$ & $\begin{array}{l}\text { Inhibition of } \\
\text { mitochondrial } \\
\text { electron transport } \\
\text { (cytochrome bc1 } \\
\text { complex) }\end{array}$ \\
\hline $\begin{array}{l}\text { Anti-viral activity } \\
\text { (in vitro, animal } \\
\text { models, } \\
\text { humans) }\end{array}$ & $\begin{array}{l}\text { Influenza virus, } \\
\text { HSV-1, DENV, } \\
\text { JCPyV, ZIKV }\end{array}$ & $\begin{array}{l}\text { CHIKV, ZIKV, DENV, EBOV, } \\
\text { coronaviruses (SARS-CoV, } \\
\text { MERS-CoV, HCoV-229E and } \\
\text { HCoV-OC43), HCV, HIV-1 } \\
\text { and-2, influenza viruses } \\
\text { (H1N1 and H3N2), } \\
\text { enteroviruses, SFTSV, NDV, } \\
\text { HSV-1 }\end{array}$ & $\begin{array}{l}\text { HCMV, HBV, HCV, HPV, CPV, } \\
\text { HIV, HHV-6, EBV, BKPyV, } \\
\text { JCPyV, EBOV }\end{array}$ & $\begin{array}{l}\text { DENV, CHIKV, } \\
\text { VSV, influenza A } \\
\text { virus }\end{array}$ & $\begin{array}{l}\text { HIV-1 (in } \\
\text { combination with } \\
\text { antiretroviral } \\
\text { therapy), KHSV }\end{array}$ & $\mathrm{CHIKV}, \mathrm{ZIKV}$ \\
\hline
\end{tabular}

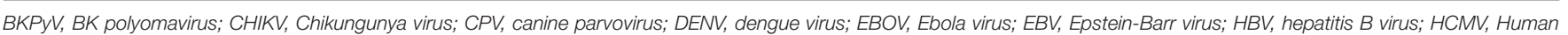

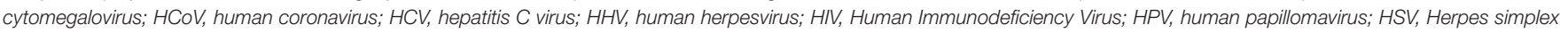

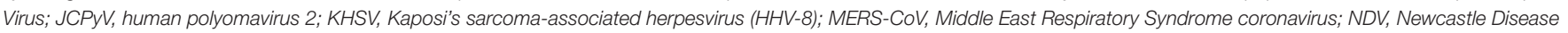

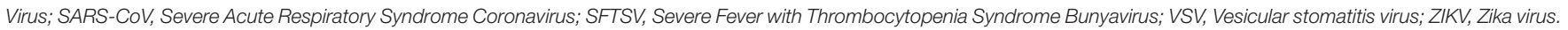

mobilized upon stimulation. Hence, interference with endosome and lysosome acidification in turn inhibits essential cell functions, e.g., proteolysis, chemotaxis, phagocytosis, phagosome conversion, and antigen presentation $(21,22)$. Importantly, CQ and HCQ similarly affect microorganismal enzymes and receptors, including virus-diverted cellular processes (8).

\section{GENERAL MECHANISMS OF CQ/HCQ ACTIONS}

CQ/HCQ affect multiple cellular processes irrespective of cell specialization (Table 2).

CQ/HCQ impair endosome-lysosome fusion through proton capture and $\mathrm{pH}$ increase, resulting in decreased clathrin expression at the plasma membrane, an endosomal stasis sometimes compared to a traffic jam upstream the lysosomal compartment, an increase in the number of intracellular vacuoles and a general decrease in endocytic trafficking and membrane receptor recycling $(8,23,24)$. Moreover, CQ/HCQ specifically downregulate plasma membrane expression of PICALM/CALM (phosphatidylinositol binding clathrin assembly lymphoid myeloid leukemia protein), a transmembrane protein involved in clathrin-mediated and probably also clathrin-independent endocytosis (8). PICALM acts as a membrane curvature sensor and clathrin-cargo adaptor $(25,26)$. PICALM downregulation provides the mechanistic explanation for membrane stabilization with CQ/HCQ (26).

Proton capture explains CQ/HCQ-induced $\mathrm{pH}$ increase and organelle deacidification, affecting any subcellular compartment with baseline $\mathrm{pH}$ lower than the surrounding cytoplasm, e.g., lysosomes, Golgi vesicles, and microsomes. CQ/HCQ thus interfere with local proteases and endosomal pattern recognition receptors (PRRs), notably toll-like receptors (TLRs), which sense viral nucleic acids (15, 19, 27, 28). Impaired endosomal/lysosomal protease activity disrupts cellular and infectious processes. Increased intraorganellar $\mathrm{pH}$ is a general mechanism hampering the intracellular development of microorganisms requiring an acidic milieu: viruses, bacteria (e.g., Coxiella burnetii, the causal agent of $\mathrm{Q}$ fever, and Tropheryma whipplei, the bacterium responsible of Whipple's disease), or fungi (e.g., Candida sp.) $(14,16)$.

Disruption of the acidic environment of intracellular vesicular compartments results in abnormal proteolytic processing and 
TABLE 2 | Main mechanisms of chloroquine and hydroxychloroquine action at the cellular level.

\begin{tabular}{|c|c|c|c|c|}
\hline Cellular compartment & Target & CQ/HCQ action & Cellular consequence & Pathophysiological implications \\
\hline \multirow[t]{2}{*}{ Plasma membrane } & $\begin{array}{l}\text { - PICALM/CALM } \\
\text { - Clathrin }\end{array}$ & $\begin{array}{l}\text { - Downregulation of } \\
\text { PICALM/CALM } \\
\\
\text { - Decreased } \\
\text { clathrin } \\
\text { expression at the } \\
\text { plasma } \\
\text { membrane }\end{array}$ & $\begin{array}{l}\text { - Plasma membrane stabilization } \\
\text { - Inhibition of clathrin-cargo fusion } \\
\text { - Defective endosome formation }\end{array}$ & $\begin{array}{l}\text { - Decreased clathrin-dependent and } \\
\text { independent endocytosis } \\
\text { - Prevention of endosome-lysosome } \\
\text { fusion } \\
\text { - Endosomal stasis } \\
\text { - Impaired plasma membrane } \\
\text { receptor recycling }\end{array}$ \\
\hline & $\begin{array}{l}\text { - Bitter taste receptors } \\
\text { (TAS2R) }\end{array}$ & - Agonist & - Inducible defense mechanisms & $\begin{array}{l}\text { - Increased NO production } \\
\text { - Increased mucociliary clearance } \\
\text { - Anti-inflammatory effects } \\
\text { - Muscle relaxation }\end{array}$ \\
\hline \multirow[t]{2}{*}{ Cytoplasm } & - MAP kinase, NF-kB & - Inhibition & $\begin{array}{l}\text { - Impairs MAPK activation and NF-kB } \\
\text { translocation }\end{array}$ & $\begin{array}{l}\text { - Downregulation of the proinflammatory } \\
\text { cascade leading to TNF } \alpha \text { and IL-6 }\end{array}$ \\
\hline & - Phospholipase A2 & - Inhibition & $\begin{array}{l}\text { - Inhibition of phospholipid mediator } \\
\text { release }\end{array}$ & $\begin{array}{l}\text { - Anti-inflammatory, anti-platelet } \\
\text { aggregate }\end{array}$ \\
\hline \multirow[t]{2}{*}{ Intracellular organelles } & $\begin{array}{l}\text { - Acidic intracellular } \\
\text { compartments }\end{array}$ & - Proton capture & $\begin{array}{l}\text { - } \mathrm{pH} \text { increases in endosomes, lysosomes, } \\
\text { Golgi vesicles, microsomes }\end{array}$ & $\begin{array}{l}\text { - Impairment of protease activity in the } \\
\text { affected organelles (cellular and viral } \\
\text { proteases, post-translational editing) } \\
\text { - Impairment of endosomal pattern } \\
\text { recognition receptors, e.g., endosomal } \\
\text { toll-like receptors } \\
\text { - Impaired antigen presentation } \\
\text { - decreased intracellular trafficking to } \\
\text { - lysosomes }\end{array}$ \\
\hline & $\begin{array}{l}\text { - Inositol-1,4,5-trisphosphate } \\
\text { receptor on the membranes } \\
\text { of intracellular } \mathrm{Ca}^{2+} \text { stores }\end{array}$ & $\begin{array}{l}\text { - Inhibition of IP3 } \\
\text { binding to its } \\
\text { receptor }\end{array}$ & $\begin{array}{l}\text { - Antagonism of intracellular } \mathrm{Ca}^{2+} \\
\text { mobilization mechanisms }\end{array}$ & $\begin{array}{l}\text { - Further impairment of efficient } \\
\text { endocytosis of the ligand-receptor } \\
\text { complexes } \\
\text { - Antagonism of cellular activation } \\
\text { - Activation of the TFEB } \\
\text { signaling pathway }\end{array}$ \\
\hline Nucleus & - DNA & - DNA intercalation & $\begin{array}{l}\text { - Replication impairment (at high CQ } \\
\text { concentrations around } 1 \mathrm{mM} \text { ) }\end{array}$ & - Anti-infectious activity \\
\hline Plasmodium & - Phagocytic vacuole & - $\beta$-hematin binding & $\begin{array}{l}\text { - Impaired heme detoxification, } \\
\text { accumulation of free hemin }\end{array}$ & - Antimalarial activity \\
\hline
\end{tabular}

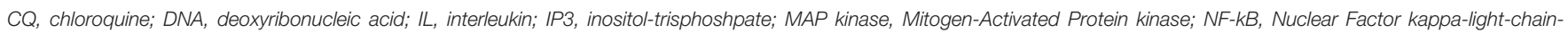

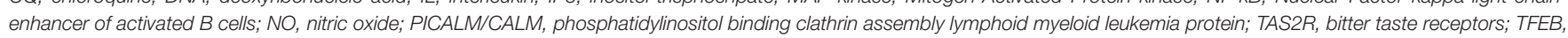
transcription factor specific for E-Box sequences; TNF $\alpha$, Tumor Necrosis Factor $\alpha$.

thus alters the post-translational steps of viral, but also cellular, protein biogenesis. This provides the first mechanistic explanation of the interference of CQ and analogs with viral replication and spread, and with host receptor, cytokine, and chemokine production. As an example, raised intravesicular $\mathrm{pH}$ interferes with the activity of glycosyltransferases, leading to abnormal glycosylation of viral envelope glycoproteins such as SARS-CoV spike (29) and Human Immunodeficiency virus (HIV)-1 gp120 (30,31). Virions carrying abnormally glycosylated envelope proteins are less infective and less prone to induce a strong cytopathogenic effect $(4,30,31)$. Impaired glycosyl transferase activity also affects terminal glycosylation of hACE2 (human angiotensin-converting enzyme 2) (29), a SARS-CoV and SARS-CoV-2 receptor $(32,33)$. CQ impairs terminal Nglycosylation, but not core glycosylation, of hACE2, which takes place in the Golgi complex, and does not alter the amount of hACE2 protein expressed by Vero-6 cells (29).

CQ/HCQ interfere with the activation of at least two signaling pathways: Mitogen-Activated Protein kinases (MAPK) and Nuclear Factor kappa-light-chain-enhancer of activated

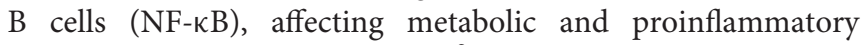
responses (34-41). Through $\mathrm{Ca}^{2+}$ release from intracellular stores, CQ/HCQ also interfere with downstream activation of TFEB (transcription factor specific for E-Box sequences), a major enhancer of gene transcription for lysosomal biogenesis, lysosomal function, and metabolic resetting of macrophages toward glycolysis, an energetic pathway associated with increased activity $(42,43)$.

Inhibition of lysosomal trafficking affects upstream (endocytosis) but also downstream (autophagy) processes. 
Autophagy inhibition is currently fueling sustained interest in CQ/HCQ as chemosensitizers for cancer therapy $(7,9,22,44-$ 46). However, autophagy inhibition also modulates dendritic cell (DC) and macrophage activation and polarization $(47,48)$. At the organ level, CQ/HCQ-induced autophagy inhibition has been reported as either protective or aggravating in cardiovascular $(49,50)$, pulmonary $(51,52)$, renal, and hepatic injuries (see below). Finally, autophagy inhibition interferes with viral replication, which needs cell constituent recycling through autophagy.

CQ is a broad-spectrum agonist of bitter taste receptors (TAS2R), a family of G-protein receptors expressed in lungs (airway smooth muscle, airway epithelial cells, lung macrophages, mast cells) and leukocytes, notably lymphocytes, innate lymphoid cells, and monocytes. TAS2R stimulation induces defense mechanisms such as an increase in NO (nitric oxide) production, stimulating mucociliary clearance and exerting antibacterial, anti-inflammatory and muscle relaxant effects (53-55).

Other experimentally identified CQ/HCQ targets include phospholipase A2 (56-59), porphyrins $(60,61)$, and even DNA at high CQ concentrations around $1 \mathrm{mM}$ (42) (Table 2).

Taken together, data summarized in this section emphasize the complexity of CQ/HCQ effects. Far from mere intravacuolar proton accepters, CQ/HCQ exert specific actions such as interference with $\mathrm{Ca}^{2+}$ intracellular signaling, plasma membrane stabilization, and direct binding to plasma membrane receptors. Some of these mechanisms have been discovered in recent years, underscoring the potential for repurposed molecules.

\section{MECHANISMS OF CQ/HCQ-INDUCED IMMUNE MODULATION}

Reports from the field of autoimmune diseases, mainly SLE, RA, and antiphospholipid syndrome (APS), have accounted for most of the twentieth century knowledge on immunomodulatory effects of CQ/HCQ. During SLE and primary APS, HCQ administration decreases levels of type I IFN in patients' serum, and expression of type I interferon (IFN)-inducible genes in peripheral blood mononuclear cells (62). In a retrospective cohort of 3,679 Spanish SLE patients, HCQ treatment conferred an odds ratio of 0.5 for polyautoimmunity (63). Healthcare registry data for 220 million individuals showed that HCQ intake was associated with a lower risk for coronary artery disease (64). This effect was replicated in vitro as HCQ-induced attenuation of human aortic endothelial cell activation upon exposure to proinflammatory cytokines (64). Overall, HCQ is considered as a safe and effective treatment for SLE, lowering the risk for clinical flares and conversely leaving patients at risk shortly after its discontinuation $(18,65)$. Outside the field of autoimmune diseases, CQ/HCQ-induced immunomodulatory effects in humans have been reported as beneficial in idiopathic interstitial pneumonia (66-68) and diabetes mellitus (69), among other conditions.

Reports of CQ/HCQ-induced immunomodulation in various diseases are associated to a broad range of actions on multiple immune cell types, and CQ/HCQ effects on measurable endpoints of the immune response are well-documented. Examples are given below.

\section{Monocytes, Macrophages and Dendritic Cells}

The monocyte-macrophage system is an important target of CQ/HCQ, especially as it orchestrates downstream modulation of $\mathrm{T}$ cell populations $(7,43)$.

CQ/HCQ modulate the monocyte-macrophage axis through multiple pathways (Figure 2), including deacidification of intracellular organelles and disruption of cytokine production. Endosomal $\mathrm{pH}$ increase disrupts nucleic acid binding to endosomal TLRs, such as TLR-3, TLR-7, and TLR-9, thereby inhibiting endosomal TLR-mediated induction of type I IFN $(19,27,28)$. In addition, one of the most prominent targets of CQ/HCQ during infection is the production of $\mathrm{TNF} \alpha$ (Tumor Necrosis Factor $\alpha$ ), a major proinflammatory cytokine driving a positive feedback loop of type 1 macrophage activation, oxygen and nitrogen reactive species generation, further proinflammatory mediators release, and more efficient phagocytosis (70). Lipopolysaccharide (LPS) signaling through TLR-4 is a potent inducer of TNF $\alpha$ release from macrophages. CQ blocks the conversion of membrane-bound TNF $\alpha$ to the soluble form and decreases the stability of interleukin (IL)-6 and IL- $1 \beta$ mRNA, thus impairing TNF $\alpha$, IL- 6 , and IL- $1 \beta$ release from LPS-stimulated macrophages (36). CQ also inhibits the NLRP3 (Nod-Like Receptor Family Pyrin domain containing 3) inflammasome in LPS-treated macrophages, targeting both the priming and the assembly signals. CQ treatment of murine and human bone marrow-derived macrophages impaired NF$\kappa \mathrm{B}$ and MAPK activation and inhibited the priming signal of NLRP3 activation, resulting in the decrease of LPS-induced IL-1 $\beta$, IL-18, and NLRP3. CQ also inhibited the second signal for NLRP3 inflammasome activation, i.e., inflammasome assembly, as shown by the lack of caspase-1 activation and ASC (apoptosis associated speck-like protein containing a CARD) specks formation (71). This may relate to altered processing of lysosomal cysteine proteases such as cathepsins $\mathrm{B}, \mathrm{C}, \mathrm{L}, \mathrm{S}$, and $\mathrm{Z}$, which are involved in NLRP3 activation (72). In vivo, CQ administration in a mouse model of endotoxic shock was associated with decreased systemic, lung, and peritoneal levels of proinflammatory cytokines IL- $1 \beta$ and IL-18, lower pulmonary levels of NLRP3 and caspase1 and improved survival (73). Similarly, HCQ inhibition of cathepsins B and L blunted NLRP3 inflammasome activation in a mouse model of renal ischemia-reperfusion injury and an in vitro model using human renal proximal tubule cells HK-2 (41).

Deacidification of the endosomes impairs activation of conventional (myeloid, mDCs) and plasmacytoid (pDCs) subsets of DCs. Decreased efficiency of endosomal TLR signaling interferes with pDCs activation, while activation of mDCs is impaired through a decrease in interleukin-1 receptor associated kinase 4 (IRAK-4) and IFN regulatory factor-7 (IRF-7) downstream MyD88 (Myeloid Differentiation primary response 


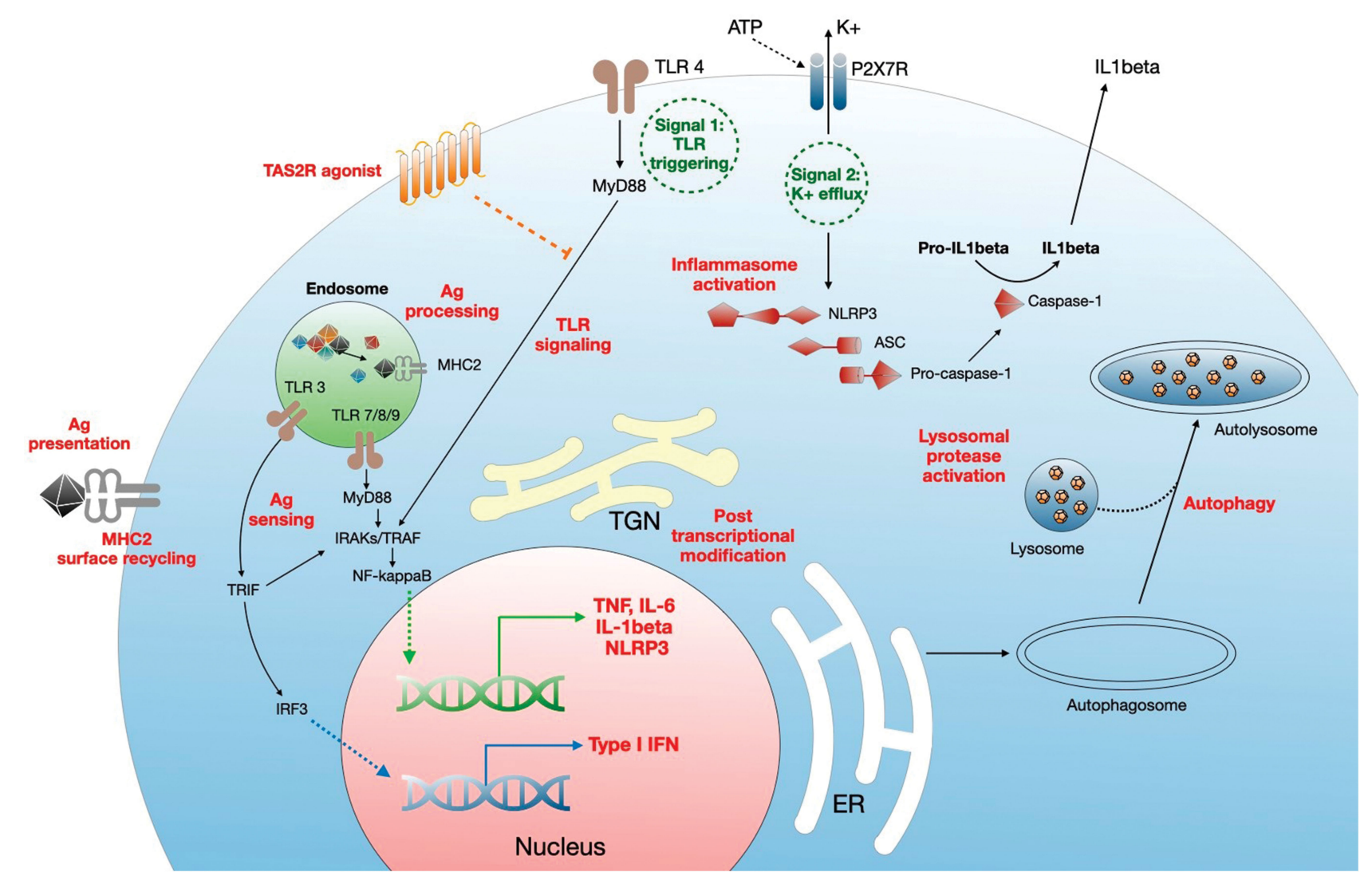

FIGURE 2 | Mechanisms of regulation of monocyte/macrophage functions by CQ/HCQ. CQ/HCQ regulate macrophage responses at different levels. First, they increase the $\mathrm{pH}$ of intracellular organelles such as endosomes, endoplasmic reticulum (RE), Golgi apparatus and trans Golgi network (TGN), and lysosomes. This results in inhibition of fusion between nascent autophagosome and lysosomes resulting in autophagy inhibition. Deacidification of TGN affects posttranscriptional modifications such as glycosylation, resulting in protein dysfunction. CQ/HCQ also increase the $\mathrm{pH}$ of endosomes, leading to alteration of antigen processing, alteration of nucleic acid sensing by endosomal TLRs (which results in decreased MyD88- and TRIF-dependent responses) and impaired antigen presentation through defective antigen (Ag) loading on MHC2 molecules, which is further diminished by reduced cell surface recycling of Ag-MHC2 complexes. CQ/HCQ affect inflammasome assembly and activation by inhibiting both signal 1 (TLR activation) and signal 2 ( $\mathrm{K}^{+}$efflux), through decreased activity of lysosomal proteases. Finally, CQ/HCQ act as a broad direct agonist for bitter taste receptors (TAS2R) at the plasma membrane, resulting in inhibition of LPS-mediated cell activation (see text for details).

88) signaling, and through downregulation of IFN $\alpha$ synthesis, collectively resulting in the downregulation of virus-induced immune activation (74).

Deacidification of intracellular organelles is not the only immunomodulatory mechanism of CQ. Extragustatory TAS2R stimulation exerts anti-inflammatory properties and bronchodilator activities, and CQ is a TAS2R agonist (5355). TAS2R stimulation in lung macrophages exposed to CQ significantly inhibited LPS-mediated production of $\mathrm{TNF} \alpha$, CCL3 (C-C motif chemokine ligand 3) and CXCL8 (C-X-C motif chemokine ligand 8 ), but also of the regulatory cytokine IL-10, suggesting that, at least in this macrophage population, inhibition of the proinflammatory cytokines was not related to IL-10 overexpression (55).

However, CQ effects may revert from protection to aggravation of the inflammatory process. For example, in the context of sterile inflammatory conditions or viral-induced cytokine storm, when macrophages receive proinflammatory signals such as exogenous IL-1 $\beta$, CQ inhibits the turn-over of plasma membrane IL-1 receptor, thus supporting persistent macrophage activation (47).

CQ/HCQ are able to re-tune tumor-associated macrophages from a permissive $\mathrm{M} 2$ to an antitumor M1 phenotype, resulting in decreased immunosuppressive cell infiltration, and enhanced antitumor T-cell immunity (7, 43). CQ treatment induced $\mathrm{Ca}^{2+}$ release from lysosomes, which in turn activated NF- $\kappa$ B, but also TFEB $(7,43)$. To our knowledge, the apparent contradiction between the classical view of CQinduced inhibition of the M1 phenotype and experiments showing macrophage reprogramming from M2 to M1 has not been addressed yet. We speculate that the precise tuning of intracellular signaling depends on macrophage microenvironment, polarization, and activation status at the initiation of the CQ/HCQ treatment, together with a possible modulation of cytokine actions on target cells, given that lysosome deacidification may impair cytotoxic effects, but also potentiate them, e.g., through autophagy-related inhibition of apoptosis. 


\section{Mast Cells (MCs) and Granulocytes}

Few studies have addressed the effects of CQ/HCQ on other innate immune cells. Nevertheless, it was reported that CQ inhibits mast cell activation after TAS2R engagement, through interference with membrane phospholipid turnover, as demonstrated in vitro by reduced histamine and prostaglandin release $(75,76)$. These observations were confirmed ex vivo in human primary MCs (38). MC cytoplasm is notoriously packed with secretory granules, which display an acidic $\mathrm{pH}$ of 5.2 to 6.1, optimal for MC proteases (77). Experiments performed with bafilomycin $\mathrm{A} 1$, an inhibitor of vacuolar-type $\mathrm{H}^{+}$-ATPase (V-ATPase) sharing with CQ/HCQ the lysosomal tropism and the ability to increase $\mathrm{pH}$ in acidic compartments, showed that disruption of the acidic $\mathrm{pH}$ of $\mathrm{MC}$ secretory granules induced tryptase degradation (77). CQ/HCQ would be expected to reproduce such findings, whose main interest resides in the abrogation of the proinflammatory signals and effectors that are conveyed by intact MC proteases, such as tryptase, the best known in humans, which is involved in chronic allergic inflammation and tissue remodeling (77-79).

CQ acting via a TAS2R-dependent mechanism was shown to exert further anti-inflammatory effects. For example, CQinduced TAS2R signaling in a mouse model of allergic asthma inhibited neutrophil and eosinophil chemotaxis, reducing disease severity (54).

Autophagy contributes to the production of neutrophil extracellular traps (NETs), which may become self-harming during COVID-19, sepsis, sterile inflammation, or thrombogenic conditions (80, 81). CQ inhibition of neutrophil autophagy has a reported beneficial effect on NETs formation and on the subsequent local and systemic inflammation (82). AMP ( $5^{\prime}$ adenosine monophosphate-activated protein) kinase is a shared target of adenosine $\mathrm{A}_{2 \mathrm{~A}}$ receptor agonists and CQ/HCQ for autophagy inhibition in neutrophils exposed to antiphospholipid antibodies (83). NETosis inhibition decreases tissue factor exposure by NETs and activated neutrophils to injured endothelium, thus alleviating the risk of thrombosis initiation (84). Given that CQ/HCQ inhibit IL-1 $\beta$ and TNF $\alpha$ production, thus decreasing neutrophil activation status and the generation of tissue factor-decorated NETs (85), it can be speculated that such convergent mechanisms of CQ/HCQ action might be beneficial during the inflammatory phase of SARS-CoV2 infection.

Finally, low doses of CQ decreased aggregation of human neutrophils stimulated with the bacterial peptide fMLP (formylmethionyl-leucyl-phenylalanine), while high doses reduced arachidonic acid liberation and thromboxane B2 formation (86), similar to experiments with stimulated platelets (56).

\section{Lymphocytes}

CQ/HCQ effects on the adaptive arm of the immune response are usually ascribed to de-acidification of endosomes and reduced activation of antigen-presenting cells, impairing antigen processing, and presentation to $\mathrm{T}$ cells (see above). However, CQ also suppresses lymphocyte proliferation through inhibition of IL-2 mRNA expression, IL-2 production, and IL-2 responsiveness (34). In addition, CQ/HCQ inhibits
$\mathrm{Ca}^{2+}$ mobilization, resulting in impaired NFAT (Nuclear factor of activated T-cells) activation and CD69 upregulation (35). Similar to macrophages, CQ affects T cell metabolism, including inhibition of autophagy, mitochondrial respiration, and anaerobic glycolysis, accompanied by decreased cytokine secretion in all $\mathrm{T}$ helper (Th) cell subsets, mainly $\mathrm{Th} 1$ and Th17 $(17,37,87)$. T cells preincubated with CQ for 7 days were fully responsive to a secondary stimulation, suggesting that $\mathrm{CQ}$ effects on proliferation were reversible (37). Accordingly, CQ/HCQ administration was beneficial in clinical settings and immunopathological mouse models involving Th1 or Th17 polarization, such as ulcerative colitis or $\operatorname{SLE}(87,88)$.

\section{Natural Killer (NK) Cells/Innate Lymphoid Cells}

Most, if not all, studies involving innate lymphocytes and $\mathrm{CQ} / \mathrm{HCQ}$ have been conducted on NK cells. Initial in vitro reports showed that $\mathrm{CQ}$ interfered at a similar extent with cytolytic activities of NK and cytotoxic lymphocytes, suggesting that CQ inhibited common pathways (89). Inhibition of NK cytolytic activities did not alter binding to target cells (90). It is suspected that CQ-induced alkalinization blocks perforin processing and maturation in secretory lysosomes, and thus perforin-dependent cytotoxicity (91). Consequently, in patients with RA, CQ therapy decreases spontaneous and IFN-induced NK activities and ameliorates the disease (92).

In conclusion, CQ/HCQ exerts direct effects on immune cell functions. Interference with lysosomal function, autophagy and signaling results in a large array of immunoregulatory activities, including less efficient immune cell activation and selective inhibition of proinflammatory cytokine production. Fine tuning of these pleiomorphic mechanisms might depend on the tissue and cellular microenvironment, the underlying chronic or acute condition, and finally, on the timing, dosing, and duration of CQ/HCQ administration in vivo.

\section{EFFECTS OF CQ/HCQ ON NON-IMMUNOLOGICAL CELL TYPES}

\section{Lung}

CQ/HCQ act on immune cells residing in the airway and pulmonary environments, but also affect structural elements such as epithelium, endothelium, smooth muscle, and fibroblasts, potentially protecting lung tissue from overt damage. CQ inhibits TLR-3 sensing and thus abrogates IL22Ral (Interleukin 22 Receptor Subunit Alpha-1) induction in normal human bronchial epithelial cells (28). IL-22 supports cell proliferation and inhibits apoptosis, thus favoring lung epithelial repair under mild viral attack, but retaining a deleterious potential in cases of serious lung viral infections. As demonstrated in A549 cells, a cell line of adenocarcinomic human alveolar basal epithelial cells, activation of TLR-3 by the H1N1 influenza virus induces type I IFN which directly upregulates the expression of IL-22Ra1 in a STAT1-dependent manner (28).

In rat bleomycin-induced pulmonary fibrosis, a model of human idiopathic pulmonary fibrosis, systemic delivery of 
cholesterol-HCQ nanocarriers attenuated the pathophysiological hallmarks of the disease: lung fibroblast proliferation, lung inflammation, and lung fibrosis (6). At the cellular level, HCQ delivery inhibited NF- $\kappa$ B and extracellular signalregulated kinases (ERK) $1 / 2$ phosphorylation, subsequent proinflammatory cytokine (TNF $\alpha)$ and profibrotic connective tissue growth factor production, bronchial recruitment of neutrophils and lymphocytes, while increasing macrophage numbers in bronchial lavage fluid.

CQ-induced inhibition of autophagy may prevent or potentiate lung function deterioration, according to the underlying condition, the immune orientation, and associated drug administration. In a murine model of allergic asthma, intranasal prophylactic and therapeutic CQ administration resulted in decreased inflammation and attenuated airway remodeling (93). In a rat model, CQ-induced inhibition of autophagy prevented the development of pulmonary arterial hypertension (51). Conversely, CQ administration following cecal puncture and ligation was associated with more severe acute lung injury and reduced survival at 7 days (52). However, improved survival was observed in murine $\mathrm{BALB} / \mathrm{c}$ endotoxic shock and attributed to the anti-NLRP3 inflammasome action of CQ, via caspase-1 inhibition (73).

Treatment of the human cancer line A549 with CQ and paclitaxel, but not with CQ alone, resulted in autophagy inhibition and mitochondrial dysregulation, accumulation of intracellular reactive oxygen species, induction of apoptosis, and cell cycle arrest (46). Autophagy inhibition by itself does not trigger apoptosis in proliferating cells (94). Inhibition of the autophagic elimination of damaged mitochondria (mitophagy) results in impaired cellular metabolism, but also prevents the release of mitochondria-associated molecular patterns, which act as proinflammatory danger signals (95), together with uncontrolled reactive oxygen species production.

HCQ treatment is beneficial in some patients suffering from surfactant-related lung diseases known as idiopathic interstitial pneumonia and including idiopathic pulmonary fibrosis (66-68), through suspected interference with intracellular processing of surfactant proteins (96).

Finally, as a broad-spectrum agonist of TAS2R, CQ increases the intracellular concentration of $\mathrm{Ca}^{2+}$ in airway smooth muscle cells through PLC $\beta$ (Phospholipase Lipase C $\beta$ ) activation, inositol-trisphosphate (IP3) production and binding to endoplasmic reticulum IP3 receptor, followed by the mobilization of $\mathrm{Ca}^{2+}$ stores (53). As a result, CQ administration results in airway smooth muscle relaxation, even in precontracted airways, thus reversing airway obstruction in human, murine, and guinea pig models (97).

\section{Endothelium}

Cardiovascular effects of CQ/HCQ have been intensively studied in the context of autoimmune diseases. In SLE patients, HCQ treatment is associated with a decrease in circulating endothelin-1, improving endothelial function and counteracting $\mathrm{TNF} \alpha$ proinflammatory stimulation in experimental murine and human endothelial HUVEC (Human Umbilical Vein Endothelial Cell) models $(18,40,49)$. In addition, through its interference with platelet phospholipase A2, HCQ inhibits platelet aggregation. This inhibition is weak, but, similar to other cationic amphiphilic drugs, HCQ inhibits the production of arachidonic acid from platelet membrane after both thrombin and $\mathrm{Ca}^{2+}$ ionophore stimulation (58). Apoptosis of endothelial cells results in increased endothelial permeability, which is associated with underlying tissue injury, notably acute lung injury. An in vitro model of human microvascular cells coupled with a C57BL/6J mouse model of ischemia/reperfusion demonstrated that CQ inhibition of autophagy, and thus of caspase-3 anti-apoptotic effect, in a context of ischemiareperfusion, accentuated lung injury (71). In the latter model, CQ not only exerted deleterious effects per se, but also prevented the effects of a beneficial anti-integrin monoclonal antibody.

CQ/HCQ effects differ between normal and diseased cardiovascular systems. In a murine model, CQ inhibited endothelial-dependent coronary vascular relaxation in control mice but increased it in diabetic TALLYHO/Jng mice (97), underscoring the special link between CQ/HCQ and type 2 diabetes which will be detailed below.

Although CQ/HCQ is effective in several inflammatory conditions, inhibition of autophagy may exert deleterious side effects and promote tissue damage and organ failure. For example, CQ/HCQ interference with autophagy and mitophagy disrupts mitochondrial turnover, resulting in the accumulation of damaged mitochondria and increased ROS, leading to impaired kidney function (98). Similar findings were observed in mouse models of acute kidney injury in which CQ/HCQ was shown to worsen the disease $(99,100)$. This effect is not restricted to the kidney, as CQ may also aggravate heart (50), lung (52), and liver (101) injury and may be potentiated by TAS2R-mediated increase of ROS production.

Taken together, these examples show that the balance of CQ/HCQ anti-inflammatory and anti-autophagic effects at the tissue level is a double-edged sword which might be beneficial or deleterious.

\section{CQ/HCQ AND CONDITIONS ASSOCIATED WITH INCREASED SEVERITY DURING COVID-19 \\ Obesity}

Overweight and obesity are associated with more severe forms of COVID-19 $(69,102)$. Chronic low-level inflammation is present in these conditions, and immune responses are altered in both systemic and adipose tissue-resident immune cells (103). Moreover, experimental data in mouse models revealed systemic immune dysregulation with decreased $\mathrm{T}$ cell progenitors in bone marrow and thymus, thymus involution, and less efficient production of antigen-specific CD8 T cells, reminiscent of clinical observations of decreased influenza vaccine protection in obese subjects (103). In healthy normal weight subjects, the resident immune population of adipose tissue is Th2-skewed and placed under the control of the anti-inflammatory adipokine adiponectin, secreted by adipocytes. A switch from adiponectin to leptin results in a repolarized local environment with increased 
levels of proinflammatory cytokines and chemokines such as TNF $\alpha$, IL-6, and MCP-1/CCL2, which in turn drive inflammatory phenotypes of immune cells (104). Overproduction of TNF $\alpha$ in the adipose tissue of obese individuals chronically stimulates lipolysis and impairs triglyceride storage. It is well-known that CQ reduces lipolysis and ameliorates systemic lipid metabolism $(105,106)$. CQ-induced reduction in lipolysis depends on adipose tissue macrophages through the alteration of lysosome function (107). Autophagy inhibition and PPAR $\gamma 2$ (Peroxisome Proliferator-Activated Receptor $\gamma 2$ ) proteosomal degradation are also observed with systemic administration of CQ, leading to impaired adipogenic differentiation and finally blocking high-fat diet-induced obesity (108).

\section{Diabetes}

HCQ is approved as a treatment for diabetes and CQ/HCQ administration to diabetic patients with COVID-19 might be associated with better outcomes (69). However, mechanistic studies suggest that CQ/HCQ may exert opposing effects in different organs, e.g., heart, kidney, or vasculature, according to the type of diabetes. For example, CQ decreased markers of kidney injury: apoptosis, oxidative stress, mitochondrial dysfunction and TGF $\beta 1$ (Transforming growth factor $\beta 1$ ) expression in human renal proximal tubular cells exposed to high glucose levels, and albuminuria and histopathologic disruption of tubular epithelium and caliber in a mouse model of streptozotocin-induced (type 1) diabetes (39). Conversely, CQ contributed to cardiac function deterioration in mice with diabetic cardiomyopathy. CQ-induced inhibition of autophagy led to divergent mechanistic effects in type 1 and type 2 diabetes models (109). At baseline, autophagy was increased in type 1 diabetic cardiomyopathy through insulin resistancerelated intracellular deficiency of glucose ("starvation"), but was inhibited in type 2 diabetes, as a consequence of a cellular overload of nutrients. Consequently, CQ affected more adversely type 2 diabetic cardiomyopathy (109).

\section{MECHANISMS OF DIRECT AND INDIRECT ANTIVIRAL ACTION OF CQ/HCQ}

CQ was one of four molecules identified among a library of 384 FDA-approved drugs as in vitro inhibitors of human coronaviruses replication (110). The three other drugs were chlorpromazine, loperamide, and lopinavir. CQ displayed broad spectrum effects against $\mathrm{HCoV}$ (human coronavirus)-229E (an alphacoronavirus), MERS-CoV (Middle East Respiratory Syndrome Coronavirus, lineage $\mathrm{C}$ of betacoronaviruses), and SARS-CoV (lineage $\mathrm{B}$ of betacoronaviruses, which includes SARS-CoV-2). In vitro experiments in Vero and Huh 7 cells confirmed that direct antiviral effects of CQ were exerted predominantly at early steps of viral replication of MERS-CoV. CQ adjunction to Vero or Huh 7 cell cultures $1 \mathrm{~h}$ prior to MERS$\mathrm{CoV}$ infection resulted in almost complete inhibition of viral replication. In contrast, CQ adjunction $1 \mathrm{~h}$ after the infection did not alter viral replication; however, the ability to reverse the cytopathic effect persisted (110). CQ/HCQ antiviral effect on
SARS-CoV-2 in vitro was documented shortly after the outbreak initiation, as a potent inhibition of viral replication in preand post-infection experiments in Vero E6 cells, with virions stalled in early endosomes and prevented from reaching the late endosome/lysosome compartment (111-113). Post-infection results suggest that $\mathrm{CQ}$ also interferes with later steps of viral replication, downstream of viral binding and entry.

CQ/HCQ deacidification of intravesicular $\mathrm{pH}$ results in virions carrying abnormally glycosylated envelope proteins, which are less infective and less prone to induce a strong cytopathogenic effect $(2,4,29)$.

Overall, viral entry, fusion with endosomes and exit might be the critically affected steps.

\section{CQ/HCQ AND COVID-19: PROS AND CONS IN THE CONTEXT OF IMMUNOMODULATORY THERAPEUTICS}

During the preparation of this manuscript, the first reports on CQ/HCQ effects in COVID-19 patients were published (3, $111,114-116)$. However, there was extreme variability in study design, study population, time after symptom onset, sample size, CQ/HCQ dosage and duration of treatment, concurrent administration of other molecules, while the methodology often did not meet the usual standards (117), leaving the reader without clear, comparable data. From a pathophysiological viewpoint, studies endorsing beneficial effects of CQ/HCQ treatment report rescued lung function, mitigated clinical and radiological abnormalities, and shortened duration of virus presence in nasopharyngeal and body fluid samples, allowing earlier discharge from hospital and reducing the risk for further spread of SARS-CoV-2 in the population. These findings suggest that CQ/HCQ administration to COVID-19 patients, especially at an early stage of the disease, provides a "flatten the curve" effect. This could start with a less aggressive viral attack on the host (Figure 3), suboptimal receptor binding, delayed delivery to the endosomes, impaired proteolysis and release of viral RNA in the cytoplasm, while exerting protective effects on lung and vascular systems, providing regulated and repolarized immune responses blunted for hyperactivation and finally a valuable gain of time for the immune system to mount an efficient immune response including adaptive features.

Combined therapeutic schemes associating CQ/HCQ and other molecules could be more efficient in fighting COVID19, e.g., CQ and remdesivir (111), or HCQ and azithromycin (114). Remdesivir is an adenosine analog which impairs viral RNA synthesis, resulting in broad-spectrum antiviral effects (111). Conversely, azithromycin is a macrolide widely used against airway infections, including prophylactic schemes for chronic obstructive bronchopulmonary diseases (118). Perhaps more importantly for the management of COVID19, azithromycin is endowed with a bimodal action on the immune system. Azithromycin administration at the early stage of a bacterial infection would promote host defenses, while at later stages with ongoing inflammation this molecule displays an array of immunomodulatory effects 


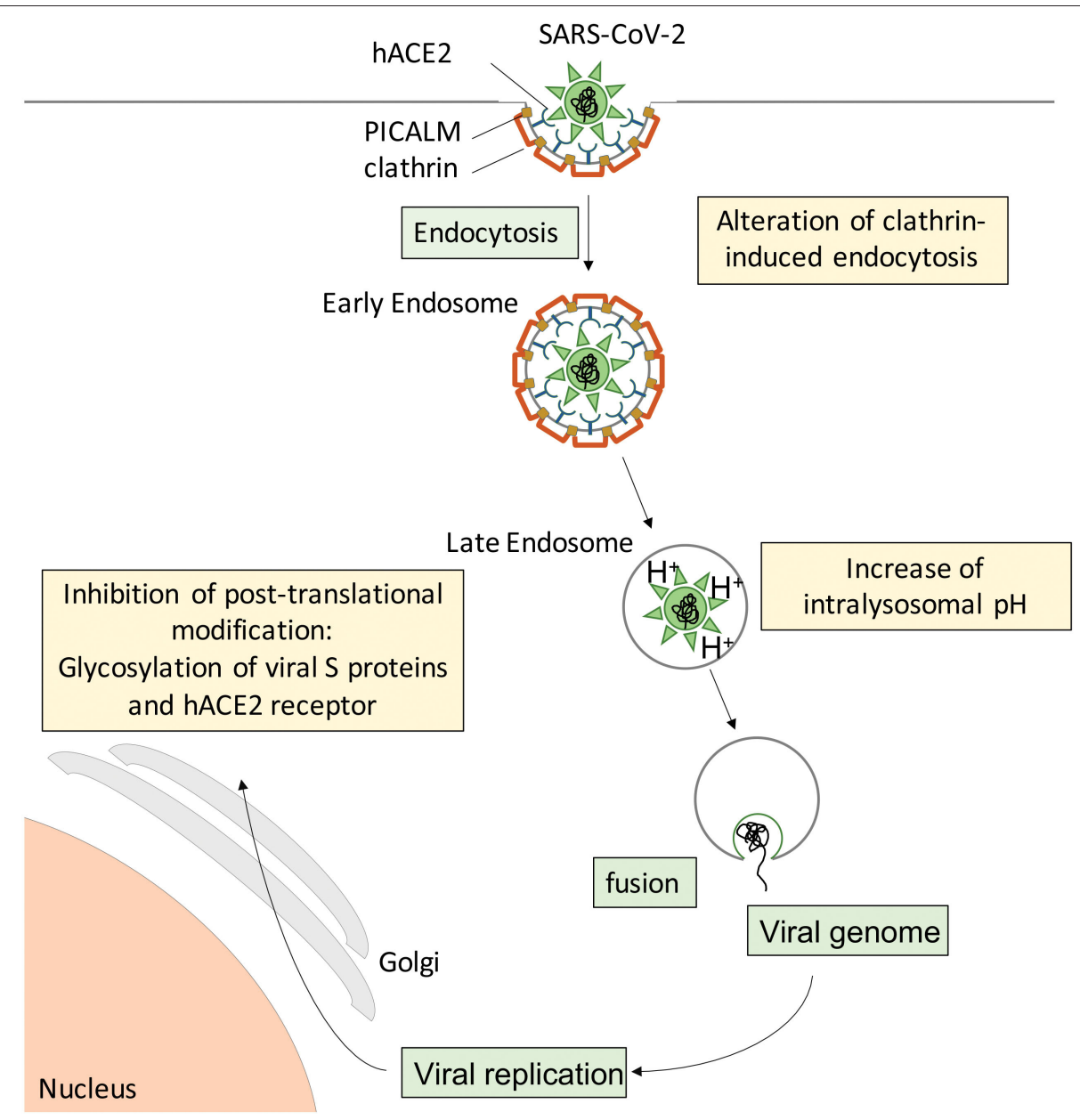

FIGURE 3 | Suspected cellular mechanisms of CQ/HCQ direct anti-SARS-CoV-2 activity. Spike S proteins from SARS-CoV-2 interact with hACE2 at the surface of target cells to induce clathrin-mediated endocytosis. CQ/HCQ may interfere with viral endocytosis by downregulating both PICALM and clathrin expression. In addition, $\mathrm{CQ}$ accumulation in the endolysosomal compartments increases the intravacuolar $\mathrm{pH}$ and reduces the fusion between the viral envelope and the endosomal membrane, resulting in reduced viral genome translocation in the cytoplasm and thus reduced viral replication. In addition, $\mathrm{CQ} / \mathrm{HCQ}$ interfere with pH-dependent glycosyltransferase activity of critical enzymes in the Golgi apparatus, thus preventing proper glycosylation of viral S proteins and their host receptor hACE2 and leading to decreased infectivity of the virions.

spanning epithelial cell protection, airway smooth muscle relaxation, inhibition of fibroblast proliferation, downregulation of neutrophil oxidative and chemotactic responses, extensive macrophage (including alveolar macrophage) modulation with $\mathrm{M} 1$ to $\mathrm{M} 2$ repolarization and inhibition of $\mathrm{TNF} \alpha, \mathrm{GM}-$ CSF (Granulocyte-macrophage colony-stimulating factor) and several proinflammatory cytokine production, and finally dendritic cell maturation toward a regulatory phenotype (119). Moreover, azithromycin accumulates in lysosomes, and HCQ has been proposed as a chemosensitizer for improved biodisponibility and prolonged efficacy of lysosomotropic drugs (7). The synergy between HCQ and azithromycin supports the emerging concept of treating SARS-CoV-2 infections with immunomodulators/immunosuppressants $(119,120)$, at least until a specific antiviral treatment is available.

In vitro and clinical data suggest that CQ/HCQ could be useful as a means of preventative control of type I IFN-induced immune activation in SARS-CoV-2 patients $(116,121)$, although other randomized, controlled studies questioned these findings (122, 123). Recent reports suggest that CQ/HCQ may not act as a rescue medication for severe cases or advanced forms with multiorgan failure (124). Experimental data show that pre-existent IL-1 induced hyperactivation of macrophages counteracts CQ/HCQ effects (47). Similarly, in vitro experiments demonstrated the loss of CQ/HCQ antiviral effects when added to cell cultures after multiple rounds of viral replication (2). Critical immune conditions and a "cytokine storm" are associated with severe forms of SARS-CoV-2 infection (120, 125). Such "cytokine storms" are a hallmark of severe forms of other viral infections, including dengue, SARS-CoV and MERS-CoV (17, 126). The "cytokine storm" step might be beyond the reach of the immune modulation and non-specific antiviral properties of CQ/HCQ. Experimental evidence suggests that COVID-19related cytokine profile is the result of immunosuppression and 
high inflammatory responses, rather than a classical "cytokine storm" (127). These findings support the view that CQ/HCQ optimal administration should be initiated early during the natural history of COVID-19 (128), rather than at a time point when an uncontrollable inflammatory response, hypoxia, respiratory distress, and multiple organ failure are unfolding in a severe condition. In such uncontrolled cases, ongoing randomized controlled studies involving biotherapies that target the C5a/C5aR pathway [eculizumab (129); avdoralimab NCT04371367] or IL-6/IL-6R pathways [tocilizumab (130)] are promising.

\section{CONCLUSION: FROM IN VITRO HOPES TO CLINICAL EFFICIENCY}

Conceptually, the use of antimalarial drugs as antiviral therapeutics relies on a combination of direct antiviral and indirect anti-inflammatory and immunomodulatory properties. Similarly, the severity of viral infections results from a combination of direct and indirect mechanisms. Among the former, uncontrolled viral replication and cytopathogenic effect are the most prominent, while the latter consist of an inappropriate immune response, with massive release of cytokines and mediators from infected target cells and activated immune cells. The monocyte-macrophage axis, helper and cytotoxic $\mathrm{T}$ cells, and innate lymphoid cells are at the stage front of this reaction, although much is yet to be learnt about the complex immune response inside infected tissues and at the hemopoietic level. The pleiomorphic immune responses reported in COVID-19, together with the impreparation of most healthcare systems to a novel pandemic agent at least partially

\section{REFERENCES}

1. Krzystyniak K, Dupuy JM. Entry of mouse hepatitis virus 3 into cells. J Gen Virol. (1984) 65(Pt 1):227-31. doi: 10.1099/0022-1317-65-1-227

2. Keyaerts E, Vijgen L, Maes P, Neyts J, Van Ranst M. In vitro inhibition of severe acute respiratory syndrome coronavirus by chloroquine. Biochem Biophys Res Commun. (2004) 323:264-8. doi: 10.1016/j.bbrc.2004.08.085

3. Gao J, Tian Z, Yang X. Breakthrough: chloroquine phosphate has shown apparent efficacy in treatment of COVID-19 associated pneumonia in clinical studies. Biosci Trends. (2020) 14:72-3. doi: 10.5582/bst.2020.01047

4. Al-Bari MAA. Targeting endosomal acidification by chloroquine analogs as a promising strategy for the treatment of emerging viral diseases. Pharmacol Res Perspect. (2017) 5:e00293. doi: 10.1002/prp2.293

5. Gilman AL, Chan KW, Mogul A, Morris C, Goldman FD, Boyer $M$, et al. Hydroxychloroquine for the treatment of chronic graftversus-host disease. Biol Blood Marrow Transplant. (2000) 6:327-34. doi: 10.1016/S1083-8791(00)70058-9

6. Liu L, Ren J, He Z, Men K, Mao Y, Ye T, et al. Cholesterol-modified hydroxychloroquine-loaded nanocarriers in bleomycin-induced pulmonary fibrosis. Sci Rep. (2017) 7:10737. doi: 10.1038/s41598-017-11450-3

7. Li Y, Cao F, Li M, Li P, Yu Y, Xiang L, et al. Hydroxychloroquine induced lung cancer suppression by enhancing chemo-sensitization and promoting the transition of M2-TAMs to M1-like macrophages. J Exp Clin Cancer Res. (2018) 37:259. doi: 10.1186/s13046-018-0938-5

8. Hu TY, Frieman M, Wolfram J. Insights from nanomedicine into chloroquine efficacy against COVID-19. Nat Nanotechnol. (2020) 15:247-9. doi: 10.1038/s41565-020-0674-9 explain the ongoing debate on CQ/HCQ utility, indications, and dosage. The ongoing clinical trials should provide the missing data for defining beyond any reasonable doubt the place of $\mathrm{CQ} / \mathrm{HCQ}$ in the management of SARS-CoV-2 infection.

\section{AUTHOR CONTRIBUTIONS}

$\mathrm{MM}, \mathrm{AB}$, and $\mathrm{AD}$ conducted the literature search. JV and $\mathrm{BD}$ extracted, synthesized the data, and wrote the manuscript. JV, $\mathrm{BD}$, and SM created the tables and figures. J-LM provided critical comments on the manuscript. All authors contributed to the conception of the review, interpretation of the data, and the revision of the manuscript.

\section{FUNDING}

This work was supported by Aix-Marseille University (AD); Fondation Méditerranée Infection doctoral fellowship (AB); Fondation Méditerranée infection postdoctoral fellowship (SM); Fondation pour la Recherche Médicale postdoctoral fellowship SPF20151234951 (SM); European funding FEDER IHU PRIMMI; French Government Investissements d'avenir (Investments for the Future); and ANR FLASH IMMUNOCOVID programs managed by the Agence Nationale de la Recherche (reference: Méditerranée Infection 10-IAHU-03); Provence-Alpes-Côte d'Azur Region.

\section{ACKNOWLEDGMENTS}

Authors were grateful to Dr. Farid Mankouri for his help during the preparation of the manuscript.

9. Varisli L, Cen O, Vlahopoulos S. Dissecting pharmacological effects of chloroquine in cancer treatment: interference with inflammatory signaling pathways. Immunology. (2020) 159:257-78. doi: 10.1111/imm.13160

10. Miller DK, Lenard J. Antihistaminics, local anesthetics, and other amines as antiviral agents. Proc Natl Acad Sci USA. (1981) 78:3605-9. doi: 10.1073/pnas.78.6.3605

11. Shibata M, Aoki H, Tsurumi T, Sugiura Y, Nishiyama Y, Suzuki $S$, et al. Mechanism of uncoating of influenza B virus in MDCK cells: action of chloroquine. J Gen Virol. (1983) 64:1149-56. doi: 10.1099/0022-1317-64-5-1149

12. Savarino A, Di Trani L, Donatelli I, Cauda R, Cassone A. New insights into the antiviral effects of chloroquine. Lancet Infect Dis. (2006) 6:67-9. doi: 10.1016/S1473-3099(06)70361-9

13. Maurin M, Benoliel AM, Bongrand P, Raoult D. Phagolysosomal alkalinization and the bactericidal effect of antibiotics: the Coxiella burnetii paradigm. J Infect Dis. (1992) 166:1097-102. doi: 10.1093/infdis/166. 5.1097

14. Ghigo E, Capo C, Aurouze M, Tung CH, Gorvel JP, Raoult D, et al. Survival of Tropheryma whipplei, the agent of Whipple's disease, requires phagosome acidification. Infect Immun. (2002) 70:1501-6. doi: 10.1128/IAI.70.3.1501-1506.2002

15. Aubry C, Corr SC, Wienerroither S, Goulard C, Jones R, Jamieson $\mathrm{AM}$, et al. Both TLR2 and TRIF contribute to interferon-beta production during Listeria infection. PLoS ONE. (2012) 7:e33299. doi: 10.1371/journal.pone.0033299

16. Rolain JM, Colson P, Raoult D. Recycling of chloroquine and its hydroxyl analogue to face bacterial, fungal and viral infections 
in the 21st century. Int $J$ Antimicrob Agents. (2007) 30:297-308. doi: 10.1016/j.ijantimicag.2007.05.015

17. D'Alessandro S, Scaccabarozzi D, Signorini L, Perego F, Ilboudo DP, Ferrante P, et al. The use of antimalarial drugs against viral infection. Microorganisms. (2020) 8:85. doi: 10.3390/microorganisms 8010085

18. Schrezenmeier E, Dorner T. Mechanisms of action of hydroxychloroquine and chloroquine: implications for rheumatology. Nat Rev Rheumatol. (2020) 16:155-66. doi: 10.1038/s41584-020-0372-x

19. Lafyatis R, York M, Marshak-Rothstein A. Antimalarial agents: closing the gate on Toll-like receptors? Arthritis Rheum. (2006) 54:3068-70. doi: $10.1002 /$ art.22157

20. Cai Y, Wang XL, Flores AM, Lin T, Guzman RJ. Inhibition of endolysosomal function exacerbates vascular calcification. Sci Rep. (2018) 8:3377. doi: 10.1038/s41598-017-17540-6

21. Kaufmann AM, Krise JP. Lysosomal sequestration of amine-containing drugs: analysis and therapeutic implications. J Pharm Sci. (2007) 96:729-46. doi: $10.1002 /$ jps.20792

22. Liu J, Liu X, Han Y, Zhang J, Liu D, Ma G, et al. Nanovaccine incorporated with hydroxychloroquine enhances antigen cross-presentation and promotes antitumor immune responses. ACS Appl Mater Interfaces. (2018) 10:30983-93. doi: 10.1021/acsami.8b09348

23. Wolfram J, Nizzero S, Liu H, Li F, Zhang G, Li Z, et al. A chloroquine-induced macrophage-preconditioning strategy for improved nanodelivery. Sci Rep. (2017) 7:13738. doi: 10.1038/s41598-017-14221-2

24. Bonam SR, Muller S, Bayry J, Klionsky DJ. Autophagy as an emerging target for COVID-19: lessons from an old friend, chloroquine. Autophagy. (2020). doi: 10.1080/15548627.2020.1779467. [Epub ahead of print].

25. Dreyling MH, Martinez-Climent JA, Zheng M, Mao J, Rowley JD, Bohlander SK. The $\mathrm{t}(10 ; 11)(\mathrm{p} 13 ; \mathrm{q} 14)$ in the U937 cell line results in the fusion of the AF10 gene and CALM, encoding a new member of the AP-3 clathrin assembly protein family. Proc Natl Acad Sci USA. (1996) 93:4804-9. doi: 10.1073/pnas.93.10.4804

26. Miller SE, Mathiasen S, Bright NA, Pierre F, Kelly BT, Kladt N, et al. CALM regulates clathrin-coated vesicle size and maturation by directly sensing and driving membrane curvature. Dev Cell. (2015) 33:163-75. doi: 10.1016/j.devcel.2015.03.002

27. Cui G, Ye X, Zuo T, Zhao H, Zhao Q, Chen W, et al. Chloroquine pretreatment inhibits toll-like receptor 3 signaling after stroke. Neurosci Lett. (2013) 548:101-4. doi: 10.1016/j.neulet.2013.02.072

28. Hebert KD, Mclaughlin N, Zhang Z, Cipriani A, Alcorn JF, Pociask DA. IL-22Ral is induced during influenza infection by direct and indirect TLR3 induction of STAT1. Respir Res. (2019) 20:184. doi: 10.1186/s12931-019-1153-4

29. Vincent MJ, Bergeron E, Benjannet S, Erickson BR, Rollin PE, Ksiazek TG, et al. Chloroquine is a potent inhibitor of SARS coronavirus infection and spread. Virol J. (2005) 2:69. doi: 10.1186/1743-422X-2-69

30. Savarino A, Lucia MB, Rastrelli E, Rutella S, Golotta C, Morra E, et al. AntiHIV effects of chloroquine: inhibition of viral particle glycosylation and synergism with protease inhibitors. J Acquir Immune Defic Syndr. (2004) 35:223-32. doi: 10.1097/00126334-200403010-00002

31. Naarding MA, Baan E, Pollakis G, Paxton WA. Effect of chloroquine on reducing HIV-1 replication in vitro and the DC-SIGN mediated transfer of virus to CD4+ T-lymphocytes. Retrovirology. (2007) 4:6. doi: 10.1186/1742-4690-4-6

32. Hoffmann M, Kleine-Weber H, Schroeder S, Kruger N, Herrler T, Erichsen S, et al. SARS-CoV-2 cell entry depends on ACE2 and TMPRSS2 and is blocked by a clinically proven protease inhibitor. Cell. (2020) 181:271-80.e278. doi: 10.1016/j.cell.2020.02.052

33. Walls AC, Park YJ, Tortorici MA, Wall A, Mcguire AT, Veesler D. Structure, function, and antigenicity of the SARS-CoV-2 spike glycoprotein. Cell. (2020) 181:281-92.e286. doi: 10.1016/j.cell.2020.02.058

34. Landewe RB, Miltenburg AM, Verdonk MJ, Verweij CL, Breedveld FC, Daha $\mathrm{MR}$, et al. Chloroquine inhibits T cell proliferation by interfering with IL2 production and responsiveness. Clin Exp Immunol. (1995) 102:144-51. doi: 10.1111/j.1365-2249.1995.tb06648.x

35. Goldman FD, Gilman AL, Hollenback C, Kato RM, Premack BA, Rawlings DJ. Hydroxychloroquine inhibits calcium signals in T cells: a new mechanism to explain its immunomodulatory properties. Blood. (2000) 95:3460-6. doi: 10.1182/blood.V95.11.3460

36. Jang CH, Choi JH, Byun MS, Jue DM. Chloroquine inhibits production of TNF-alpha, IL-1beta and IL-6 from lipopolysaccharide-stimulated human monocytes/macrophages by different modes. Rheumatology. (2006) 45:70310. doi: 10.1093/rheumatology/kei282

37. Schmidt RL, Jutz S, Goldhahn K, Witzeneder N, Gerner MC, Trapin D, et al. Chloroquine inhibits human CD4(+) T-cell activation by AP-1 signaling modulation. Sci Rep. (2017) 7:42191. doi: 10.1038/srep42191

38. Espinosa E, Valitutti S, Laroche M, Laurent C, Apoil PA, Hermine O, et al. Hydroxychloroquine as a novel therapeutic approach in mast cell activation diseases. Clin Immunol. (2018) 194:75-9. doi: 10.1016/j.clim.2018.07.004

39. Jeong HY, Kang JM, Jun HH, Kim DJ, Park SH, Sung MJ, et al. Chloroquine and amodiaquine enhance AMPK phosphorylation and improve mitochondrial fragmentation in diabetic tubulopathy. Sci Rep. (2018) 8:8774. doi: 10.1038/s41598-018-26858-8

40. Li R, Lin H, Ye Y, Xiao Y, Xu S, Wang J, et al. Attenuation of antimalarial agent hydroxychloroquine on TNF-alpha-induced endothelial inflammation. Int Immunopharmacol. (2018) 63:261-9. doi: 10.1016/j.intimp.2018.08.008

41. Tang TT, Lv LL, Pan MM, Wen Y, Wang B, Li ZL, et al. Hydroxychloroquine attenuates renal ischemia/reperfusion injury by inhibiting cathepsin mediated NLRP3 inflammasome activation. Cell Death Dis. (2018) 9:351. doi: 10.1038/s41419-018-0378-3

42. Misra UK, Gawdi G, Pizzo SV. Chloroquine, quinine and quinidine inhibit calcium release from macrophage intracellular stores by blocking inositol 1,4,5-trisphosphate binding to its receptor. J Cell Biochem. (1997) 64:225-32. doi: 10.1002/(SICI) 1097-4644(199702)64:2<225::AID-JCB6>3.0.CO;2-Z

43. Chen D, Xie J, Fiskesund R, Dong W, Liang X, Lv J, et al. Chloroquine modulates antitumor immune response by resetting tumor-associated macrophages toward M1 phenotype. Nat Commun. (2018) 9:873. doi: 10.1038/s41467-018-03225-9

44. Lamattina AM, Taveira-Dasilva A, Goldberg HJ, Bagwe S, Cui Y, Rosas IO, et al. Circulating biomarkers from the phase 1 trial of sirolimus and autophagy inhibition for patients with lymphangioleiomyomatosis. Chest. (2018) 154:1070-82. doi: 10.1016/j.chest.2018.08.1029

45. Mauthe M, Orhon I, Rocchi C, Zhou X, Luhr M, Hijlkema $\mathrm{KJ}$, et al. Chloroquine inhibits autophagic flux by decreasing autophagosome-lysosome fusion. Autophagy. (2018) 14:1435-55. doi: 10.1080/15548627.2018.1474314

46. Datta S, Choudhury D, Das A, Mukherjee DD, Dasgupta M, Bandopadhyay $\mathrm{S}$, et al. Autophagy inhibition with chloroquine reverts paclitaxel resistance and attenuates metastatic potential in human nonsmall lung adenocarcinoma A549 cells via ROS mediated modulation of beta-catenin pathway. Apoptosis. (2019) 24:414-33. doi: 10.1007/s10495-019-01526-y

47. Lubow C, Bockstiegel J, Weindl G. Lysosomotropic drugs enhance pro-inflammatory responses to IL-1beta in macrophages by inhibiting internalization of the IL-1 receptor. Biochem Pharmacol. (2020) 175:113864. doi: 10.1016/j.bcp.2020.113864

48. Ghislat G, Lawrence T. Autophagy in dendritic cells. Cell Mol Immunol. (2018) 15:944-52. doi: $10.1038 / \mathrm{cmi} .2018 .2$

49. Rahman R, Murthi P, Singh H, Gurusinghe S, Mockler JC, Lim R, et al. The effects of hydroxychloroquine on endothelial dysfunction. Pregnancy Hypertens. (2016) 6:259-62. doi: 10.1016/j.preghy.2016.09.001

50. Ma X, Liu H, Foyil SR, Godar RJ, Weinheimer CJ, Hill JA, et al. Impaired autophagosome clearance contributes to cardiomyocyte death in ischemia/reperfusion injury. Circulation. (2012) 125:3170-81. doi: 10.1161/CIRCULATIONAHA.111.041814

51. Racanelli AC, Kikkers SA, Choi AMK, Cloonan SM. Autophagy and inflammation in chronic respiratory disease. Autophagy. (2018) 14:221-32. doi: $10.1080 / 15548627.2017 .1389823$

52. Zhao H, Chen H, Xiaoyin M, Yang G, Hu Y, Xie K, et al. Autophagy activation improves lung injury and inflammation in sepsis. Inflammation. (2019) 42:426-39. doi: 10.1007/s10753-018-00952-5

53. Deshpande DA, Wang WC, Mcilmoyle EL, Robinett KS, Schillinger RM, An SS, et al. Bitter taste receptors on airway smooth muscle bronchodilate by localized calcium signaling and reverse obstruction. Nat Med. (2010) 16:1299-304. doi: $10.1038 / \mathrm{nm} .2237$ 
54. Sharma P, Yi R, Nayak AP, Wang N, Tang F, Knight MJ, et al. Bitter taste receptor agonists mitigate features of allergic asthma in mice. Sci Rep. (2017) 7:46166. doi: $10.1038 /$ srep46166

55. Grassin-Delyle S, Salvator H, Mantov N, Abrial C, Brollo M, Faisy C, et al. Bitter taste receptors (TAS2Rs) in human lung macrophages: receptor expression and inhibitory effects of TAS2R agonists. Front Physiol. (2019) 10:1267. doi: 10.3389/fphys.2019.01267

56. Nosal R, Jancinova V, Petrikova M. Chloroquine inhibits stimulated platelets at the arachidonic acid pathway. Thromb Res. (1995) 77:531-42. doi: 10.1016/0049-3848(95)00028-3

57. Kotuliakova K, Nosal R, Pecivova J, Drabikova K, Macickova T. Human polymorphonuclear leukocytes: effect of chloroquine on aggregation, arachidonic acid liberation and thromboxane B2 generation. Gen Physiol Biophys. (1996) 15:489-94.

58. Nosal R, Jancinova V. Cationic amphiphilic drugs and platelet phospholipase $\mathrm{A}_{2}\left(\mathrm{cPLA}_{2}\right)$. Thromb Res. (2002) 105:339-45. doi: 10.1016/S0049-3848(02)00036-1

59. Farooqui AA, Ong WY, Horrocks LA. Inhibitors of brain phospholipase A2 activity: their neuropharmacological effects and therapeutic importance for the treatment of neurologic disorders. Pharmacol Rev. (2006) 58:591-620. doi: $10.1124 /$ pr.58.3.7

60. Herraiz T, Guillen H, Gonzalez-Pena D, Aran VJ. Antimalarial quinoline drugs inhibit beta-hematin and increase free hemin catalyzing peroxidative reactions and inhibition of cysteine proteases. Sci Rep. (2019) 9:15398. doi: 10.1038/s41598-019-51604-Z

61. Kapishnikov S, Staalso T, Yang Y, Lee J, Perez-Berna AJ, Pereiro E, et al. Mode of action of quinoline antimalarial drugs in red blood cells infected by Plasmodium falciparum revealed in vivo. Proc Natl Acad Sci USA. (2019) 116:22946-52. doi: 10.1073/pnas.1910123116

62. van Den Hoogen LL, Fritsch-Stork RD, Versnel MA, Derksen RH, Van Roon JA, Radstake TR. Monocyte type I interferon signature in antiphospholipid syndrome is related to proinflammatory monocyte subsets, hydroxychloroquine and statin use. Ann Rheum Dis. (2016) 75:e81. doi: 10.1136/annrheumdis-2016-210485

63. Mena-Vazquez N, Fernandez-Nebro A, Pego-Reigosa JM, Galindo M, Melissa-Anzola A, Uriarte-Isacelay E, et al. Hydroxychloroquine is associated with a lower risk of polyautoimmunity: data from the RELESSER registry. Rheumatology. (2019) 59:2043-51. doi: 10.1093/rheumatology/kez562

64. Cheng F, Desai RJ, Handy DE, Wang R, Schneeweiss S, Barabasi $\mathrm{AL}$, et al. Network-based approach to prediction and population-based validation of in silico drug repurposing. Nat Commun. (2018) 9:2691. doi: 10.1038/s41467-018-05116-5

65. Costedoat-Chalumeau N, Amoura Z, Hulot JS, Hammoud HA, Aymard G, Cacoub P, et al. Low blood concentration of hydroxychloroquine is a marker for and predictor of disease exacerbations in patients with systemic lupus erythematosus. Arthritis Rheum. (2006) 54:3284-90. doi: 10.1002/art.22156

66. Beers MF. Inhibition of cellular processing of surfactant protein $\mathrm{C}$ by drugs affecting intracellular pH gradients. J Biol Chem. (1996) 271:14361-70. doi: $10.1074 /$ jbc.271.24.14361

67. Kroner C, Wittmann T, Reu S, Teusch V, Klemme M, Rauch D, et al. Lung disease caused by ABCA3 mutations. Thorax. (2017) 72:213-20. doi: 10.1136/thoraxjnl-2016-208649

68. Klay D, Hoffman TW, Harmsze AM, Grutters JC, Van Moorsel CHM. Systematic review of drug effects in humans and models with surfactant-processing disease. Eur Respir Rev. (2018) 27:170135. doi: 10.1183/16000617.0135-2017

69. Muniyappa R, Gubbi S. COVID-19 pandemic, coronaviruses, and diabetes mellitus. Am J Physiol Endocrinol Metab. (2020) 318:E736-41. doi: 10.1152/ajpendo.00124.2020

70. Hamidzadeh K, Christensen SM, Dalby E, Chandrasekaran P, Mosser DM. Macrophages and the recovery from acute and chronic inflammation. Annu Rev Physiol. (2017) 79:567-92. doi: 10.1146/annurev-physiol-022516034348

71. Zhang D, Li C, Song Y, Zhou J, Li Y, Li J, et al. Integrin alphavbeta5 inhibition protects against ischemia-reperfusion-induced lung injury in an autophagy-dependent manner. Am J Physiol Lung Cell Mol Physiol. (2017) 313:L384-1394. doi: 10.1152/ajplung.00391.2016
72. Orlowski GM, Colbert JD, Sharma S, Bogyo M, Robertson SA, Rock KL. Multiple cathepsins promote pro-IL-1beta synthesis and NLRP3-mediated IL-1beta activation. J Immunol. (2015) 195:1685-97. doi: 10.4049/jimmunol.1500509

73. Chen X, Wang N, Zhu Y, Lu Y, Liu X, Zheng J. The antimalarial chloroquine suppresses LPS-induced NLRP3 inflammasome activation and confers protection against murine endotoxic shock. Mediators Inflamm. (2017) 2017:6543237. doi: 10.1155/2017/6543237

74. Martinson JA, Montoya CJ, Usuga X, Ronquillo R, Landay AL, Desai SN. Chloroquine modulates HIV-1-induced plasmacytoid dendritic cell alpha interferon: implication for T-cell activation. Antimicrob Agents Chemother. (2010) 54:871-81. doi: 10.1128/AAC.01246-09

75. Nosal R, Drabikova K, Pecivova J. Effect of chloroquine on isolated mast cells. Agents Actions. (1991) 33:37-40. doi: 10.1007/BF01993121

76. Ekoff M, Choi JH, James A, Dahlen B, Nilsson G, Dahlen SE. Bitter taste receptor (TAS2R) agonists inhibit IgE-dependent mast cell activation. J Allergy Clin Immunol. (2014) 134:475-8. doi: 10.1016/j.jaci.2014.02.029

77. Pejler G, Hu Frisk JM, Sjostrom D, Paivandy A, Ohrvik H. Acidic pH is essential for maintaining mast cell secretory granule homeostasis. Cell Death Dis. (2017) 8:e2785. doi: 10.1038/cddis.2017.206

78. Vitte J. Human mast cell tryptase in biology and medicine. Mol Immunol. (2015) 63:18-24. doi: 10.1016/j.molimm.2014.04.001

79. Huber M, Cato ACB, Ainooson GK, Freichel M, Tsvilovskyy V, Jessberger $\mathrm{R}$, et al. Regulation of the pleiotropic effects of tissue-resident mast cells. $J$ Allergy Clin Immunol. (2019) 144:S31-s45. doi: 10.1016/j.jaci.2019.02.004

80. Pham DL, Ban GY, Kim SH, Shin YS, Ye YM, Chwae YJ, et al. Neutrophil autophagy and extracellular DNA traps contribute to airway inflammation in severe asthma. Clin Exp Allergy. (2017) 47:57-70. doi: 10.1111/cea.12859

81. Zuo Y, Yalavarthi S, Shi H, Gockman K, Zuo M, Madison JA, et al. Neutrophil extracellular traps in COVID-19. JCI Insight. (2020) 5:e138999. doi: 10.1101/2020.04.30.20086736

82. Murthy P, Singhi AD, Ross MA, Loughran P, Paragomi P, Papachristou GI, et al. Enhanced neutrophil extracellular trap formation in acute pancreatitis contributes to disease severity and is reduced by chloroquine. Front Immunol. (2019) 10:28. doi: 10.3389/fimmu.2019.00028

83. Ali RA, Gandhi AA, Meng H, Yalavarthi S, Vreede AP, Estes SK, et al. Adenosine receptor agonism protects against NETosis and thrombosis in antiphospholipid syndrome. Nat Commun. (2019) 10:1916. doi: 10.1038/s41467-019-09801-x

84. Liberale L, Holy EW, Akhmedov A, Bonetti NR, Nietlispach F, Matter $\mathrm{CM}$, et al. Interleukin-1beta mediates arterial thrombus formation via NETassociated tissue factor. J Clin Med. (2019) 8:2072. doi: 10.3390/jcm8122072

85. Kambas K, Mitroulis I, Apostolidou E, Girod A, Chrysanthopoulou A, Pneumatikos I, et al. Autophagy mediates the delivery of thrombogenic tissue factor to neutrophil extracellular traps in human sepsis. PLoS ONE. (2012) 7:e45427. doi: 10.1371/journal.pone.0045427

86. Nagar J, Ranade S, Kamath V, Singh S, Karunanithi P, Subramani $\mathrm{S}$, et al. Therapeutic potential of chloroquine in a murine model of inflammatory bowel disease. Int Immunopharmacol. (2014) 21:328-35. doi: 10.1016/j.intimp.2014.05.005

87. An N, Chen Y, Wang C, Yang C, Wu ZH, Xue J, et al. Chloroquine autophagic inhibition rebalances Th17/Treg-mediated immunity and ameliorates systemic lupus erythematosus. Cell Physiol Biochem. (2017) 44:412-22. doi: $10.1159 / 000484955$

88. Goenka MK, Kochhar R, Tandia B, Mehta SK. Chloroquine for mild to moderately active ulcerative colitis: comparison with sulfasalazine. Am J Gastroenterol. (1996) 91:917-21.

89. Ausiello C, Sorrentino V, Ruggiero V, Rossi GB. Action of lysosomotropic amines on spontaneous and interferon enhanced NK and CTL cytolysis. Immunol Lett. (1984) 8:11-5. doi: 10.1016/0165-2478(84)90097-X

90. Pedersen BK, Bygbjerg IC, Theander TG, Andersen BJ. Effects of chloroquine, mefloquine and quinine on natural killer cell activity in vitro. An analysis of the inhibitory mechanism. Allergy. (1986) 41:537-42. doi: 10.1111/j.1398-9995.1986.tb00340.x

91. Austin Taylor M, Bennett M, Kumar V, Schatzle JD. Functional defects of NK cells treated with chloroquine mimic the lytic defects observed in perforin-deficient mice. J Immunol. (2000) 165:5048-53. doi: 10.4049/jimmunol.165.9.5048 
92. Ausiello CM, Barbieri P, Spagnoli GC, Ciompi ML, Casciani CU. In vivo effects of chloroquine treatment on spontaneous and interferon-induced natural killer activities in rheumatoid arthritis patients. Clin Exp Rheumatol. (1986) 4:255-9.

93. McAlinden KD, Deshpande DA, Ghavami S, Xenaki D, Sohal SS, Oliver BG, et al. Autophagy activation in asthma airways remodeling. Am J Respir Cell Mol Biol. (2019) 60:541-53. doi: 10.1165/rcmb.2018-0169OC

94. Vera-Ramirez L, Vodnala SK, Nini R, Hunter KW, Green JE. Autophagy promotes the survival of dormant breast cancer cells and metastatic tumour recurrence. Nat Commun. (2018) 9:1944. doi: 10.1038/s41467-018-04070-6

95. Lin JY, Jing R, Lin F, Ge WY, Dai HJ, Pan L. High tidal volume induces mitochondria damage and releases mitochondrial DNA to aggravate the ventilator-induced lung injury. Front Immunol. (2018) 9:1477. doi: 10.3389/fimmu.2018.01477

96. Larsson OJ, Manson ML, Starkhammar M, Fuchs B, Adner M, Kumlien Georen S, et al. The TLR7 agonist imiquimod induces bronchodilation via a nonneuronal TLR7-independent mechanism: a possible role for quinoline in airway dilation. Am J Physiol Lung Cell Mol Physiol. (2016) 310:L1121-9. doi: 10.1152/ajplung.00288.2015

97. Zhang Q, Tsuji-Hosokawa A, Willson C, Watanabe M, Si R, Lai N, et al. Chloroquine differentially modulates coronary vasodilation in control and diabetic mice. Br J Pharmacol. (2020) 177:314-27. doi: 10.1111/bph.14864

98. Festa BP, Chen Z, Berquez M, Debaix H, Tokonami N, Prange JA, et al. Impaired autophagy bridges lysosomal storage disease and epithelial dysfunction in the kidney. Nat Commun. (2018) 9:161. doi: 10.1038/s41467-017-02536-7

99. Jiang M, Wei Q, Dong G, Komatsu M, Su Y, Dong Z. Autophagy in proximal tubules protects against acute kidney injury. Kidney Int. (2012) 82:1271-83. doi: 10.1038/ki.2012.261

100. Mei S, Livingston M, Hao J, Li L, Mei C, Dong Z. Autophagy is activated to protect against endotoxic acute kidney injury. Sci Rep. (2016) 6:22171. doi: $10.1038 /$ srep 22171

101. Lin CW, Lo S, Perng DS, Wu DB, Lee PH, Chang YF, et al. Complete activation of autophagic process attenuates liver injury and improves survival in septic mice. Shock. (2014) 41:241-9. doi: 10.1097/SHK.0000000000000111

102. Singh AK, Singh A, Shaikh A, Singh R, Misra A. Chloroquine and hydroxychloroquine in the treatment of COVID-19 with or without diabetes: a systematic search and a narrative review with a special reference to India and other developing countries. Diabetes Metab Syndr. (2020) 14:241-6. doi: 10.1016/j.dsx.2020.03.011

103. Turbitt WJ, Buchta Rosean C, Weber KS, Norian LA. Obesity and CD8 $\mathrm{T}$ cell metabolism: Implications for anti-tumor immunity and cancer immunotherapy outcomes. Immunol Rev. (2020) 295:203-19. doi: 10.1111/imr.12849

104. Frasca D, Diaz A, Romero M, Blomberg BB. Leptin induces immunosenescence in human B cells. Cell Immunol. (2020) 348:103994. doi: 10.1016/j.cellimm.2019.103994

105. Powrie JK, Shojaee-Moradie F, Watts GF, Smith GD, Sonksen PH, Jones RH. Effects of chloroquine on the dyslipidemia of noninsulin-dependent diabetes mellitus. Metabolism. (1993) 42:415-9. doi: 10.1016/0026-0495(93)90096-7

106. Benoit FL. The inhibitory effect of chloroquine on rat adipose tissue metabolism in vitro. Metabolism. (1967) 16:557-61. doi: 10.1016/0026-0495(67)90086-8

107. Xu X, Grijalva A, Skowronski A, Van Eijk M, Serlie MJ, Ferrante AW Jr. Obesity activates a program of lysosomal-dependent lipid metabolism in adipose tissue macrophages independently of classic activation. Cell Metab. (2013) 18:816-30. doi: 10.1016/j.cmet.2013.11.001

108. Zhang C, He Y, Okutsu M, Ong LC, Jin Y, Zheng L, et al. Autophagy is involved in adipogenic differentiation by repressesing proteasomedependent PPARgamma2 degradation. Am J Physiol Endocrinol Metab. (2013) 305:E530-9. doi: 10.1152/ajpendo.00640.2012

109. Kanamori H, Takemura G, Goto K, Tsujimoto A, Mikami A, Ogino A, et al. Autophagic adaptations in diabetic cardiomyopathy differ between type 1 and type 2 diabetes. Autophagy. (2015) 11:1146-60. doi: 10.1080/15548627.2015.1051295

110. de Wilde AH, Jochmans D, Posthuma CC, Zevenhoven-Dobbe JC, Van Nieuwkoop S, Bestebroer TM, et al. Screening of an FDA-approved compound library identifies four small-molecule inhibitors of Middle East respiratory syndrome coronavirus replication in cell culture. Antimicrob Agents Chemother. (2014) 58:4875-84. doi: 10.1128/AAC.03011-14

111. Wang M, Cao R, Zhang L, Yang X, Liu J, Xu M, et al. Remdesivir and chloroquine effectively inhibit the recently emerged novel coronavirus (2019-nCoV) in vitro. Cell Res. (2020) 30:269-71. doi: 10.1038/s41422-020-0282-0

112. Liu J, Cao R, Xu M, Wang X, Zhang H, Hu H, et al. Hydroxychloroquine, a less toxic derivative of chloroquine, is effective in inhibiting SARS-CoV-2 infection in vitro. Cell Discov. (2020) 6:16. doi: 10.1038/s41421-020-0156-0

113. Yao X, Ye F, Zhang M, Cui C, Huang B, Niu P, et al. In vitro antiviral activity and projection of optimized dosing design of hydroxychloroquine for the treatment of severe acute respiratory syndrome coronavirus 2 (SARS-CoV2). Clin Infect Dis. (2020) 71:732-9. doi: 10.1093/cid/ciaa237

114. Colson P, Rolain JM, Lagier JC, Brouqui P, Raoult D. Chloroquine and hydroxychloroquine as available weapons to fight COVID-19. Int J Antimicrob Agents. (2020) 55:105932. doi: 10.1016/j.ijantimicag.2020.105932

115. Huang M, Li M, Xiao F, Pang P, Liang J, Tang T, et al. Preliminary evidence from a multicenter prospective observational study of the safety and efficacy of chloroquine for the treatment of COVID-19. Natl Sci Rev. (2020). doi: 10.1093/nsr/nwaa113. [Epub ahead of print].

116. Millan-Onate J, Millan W, Mendoza LA, Sanchez CG, Fernandez-Suarez H, Bonilla-Aldana DK, et al. Successful recovery of COVID-19 pneumonia in a patient from Colombia after receiving chloroquine and clarithromycin. Ann Clin Microbiol Antimicrob. (2020) 19:16. doi: 10.1186/s12941-020-00358-y

117. Meyerowitz EA, Vannier AGL, Friesen MGN, Schoenfeld S, Gelfand JA, Callahan MV, et al. Rethinking the role of hydroxychloroquine in the treatment of COVID-19. FASEB J. (2020) 34:6027-37. doi: 10.1096/fj.202000919

118. Parnham MJ, Erakovic Haber V, Giamarellos-Bourboulis EJ, Perletti G, Verleden GM, Vos R. Azithromycin: mechanisms of action and their relevance for clinical applications. Pharmacol Ther. (2014) 143:225-45. doi: 10.1016/j.pharmthera.2014.03.003

119. Zhang W, Zhao Y, Zhang F, Wang Q, Li T, Liu Z, et al. The use of antiinflammatory drugs in the treatment of people with severe coronavirus disease 2019 (COVID-19): the perspectives of clinical immunologists from China. Clin Immunol. (2020) 214:108393. doi: 10.1016/j.clim.2020.108393

120. Mehta P, Mcauley DF, Brown M, Sanchez E, Tattersall RS, Manson JJ. COVID-19: consider cytokine storm syndromes and immunosuppression. Lancet. (2020) 395:1033-4. doi: 10.1016/S0140-6736(20) 30628-0

121. Gautret P, Lagier JC, Parola P, Hoang VT, Meddeb L, Sevestre J, et al. Clinical and microbiological effect of a combination of hydroxychloroquine and azithromycin in 80 COVID-19 patients with at least a six-day follow up: a pilot observational study. Travel Med Infect Dis. (2020) 101663. doi: 10.1016/j.tmaid.2020.101663

122. Chen J, Liu D, Liu L, Liu P, Xu Q, Xia L, et al. A pilot study of hydroxychloroquine in treatment of patients with common coronavirus disease-19 (COVID-19). J Zhejiang Univ. (2020) 49:215-9. doi: $10.3785 /$ j.issn.1008-9292.2020.03.03

123. Magagnoli J, Narendran S, Pereira F, Cummings TH, Hardin JW, Sutton SS, et al. Outcomes of hydroxychloroquine usage in united states veterans hospitalized with COVID-19. Med (NY). (2020). doi: 10.1016/j.medj.2020.06.001. [Epub ahead of print].

124. Molina JM, Delaugerre C, Le Goff J, Mela-Lima B, Ponscarme D, Goldwirt L, et al. No evidence of rapid antiviral clearance or clinical benefit with the combination of hydroxychloroquine and azithromycin in patients with severe COVID-19 infection. Med Mal Infect. (2020) 50:384. doi: 10.1016/j.medmal.2020.03.006

125. Guo YR, Cao QD, Hong ZS, Tan YY, Chen SD, Jin HJ, et al. The origin, transmission and clinical therapies on coronavirus disease 2019 (COVID-19) outbreak - an update on the status. Mil Med Res. (2020) 7:11. doi: 10.1186/s40779-020-00240-0

126. Xiong Y, Liu Y, Cao L, Wang D, Guo M, Jiang A, et al. Transcriptomic characteristics of bronchoalveolar lavage fluid and peripheral blood mononuclear cells in COVID-19 patients. Emerg Microbes Infect. (2020) 9:761-70. doi: 10.1080/22221751.2020. 1747363 
127. Remy KE, Mazer M, Striker DA, Ellebedy AH, Walton AH, Unsinger J, et al. Severe immunosuppression and not a cytokine storm characterize COVID-19 infections. JCI Insight. (2020). doi: 10.1172/jci.insight.140329. [Epub ahead of print].

128. Borba MGS, Val FFA, Sampaio VS, Alexandre MAA, Melo GC, Brito M, et al. Effect of high vs low doses of chloroquine diphosphate as adjunctive therapy for patients hospitalized with severe acute respiratory syndrome coronavirus 2 (SARS-CoV-2) infection: a randomized clinical trial. JAMA Netw Open. (2020) 3:e208857. doi: 10.1001/jamanetworkopen.2020.8857

129. Diurno F, Numis FG, Porta G, Cirillo F, Maddaluno S, Ragozzino A, et al. Eculizumab treatment in patients with COVID-19: preliminary results from real life ASL Napoli 2 Nord experience. Eur Rev Med Pharmacol Sci. (2020) 24:4040-7. doi: 10.26355/eurrev_202004_20875

130. Xu X, Han M, Li T, Sun W, Wang D, Fu B, et al. Effective treatment of severe COVID-19 patients with tocilizumab. Proc Natl Acad Sci USA. (2020) 117:10970-5. doi: 10.1073/pnas.2005615117
Conflict of Interest: JV reports personal fees from Thermo Fisher Scientific, personal fees from Meda Pharma (Mylan), personal fees from Beckman Coulter, personal fees from Sanofi, outside the submitted work.

The remaining authors declare that the research was conducted in the absence of any commercial or financial relationships that could be construed as a potential conflict of interest.

Copyright (C) 2020 Vitte, Michel, Mezouar, Diallo, Boumaza, Mege and Desnues. This is an open-access article distributed under the terms of the Creative Commons Attribution License (CC BY). The use, distribution or reproduction in other forums is permitted, provided the original author(s) and the copyright owner(s) are credited and that the original publication in this journal is cited, in accordance with accepted academic practice. No use, distribution or reproduction is permitted which does not comply with these terms. 